\title{
Discussion on Islamic Finance and Small Medium Enterprises' Financial Accessibility
}

\author{
Hassanudin Mohd Thas Thaker ${ }^{1 *}$ \& K Chandra Sakaran ${ }^{2}$ \\ ${ }^{*}$ Corresponding author
}

\begin{abstract}
This study attempts to provide some understanding of SMEs' access to finance in Malaysia using Islamic finance and its successfulness. The innovation that taking place in the Malaysia financial landscape has benefits the SMEs in accessing financial assistance without relying on the traditional mode of financing. The role of government of Malaysia is also undisputable in supporting the progression of SMEs via various policy implementation. Apparently, in the context of Indonesia, the role SMEs is also undeniable in boosting up the growth of Indonesian economy. Statistically speaking, SMEs in Indonesia represent about 99 percent in all economic sector and involved labor participation of almost 95 percent. Although the contributions are wider, the issue of financial accessibility still becomes one of the main hurdles that block the development of SMEs in Indonesia. Therefore, the present study has used content analysis to critically look at the success of SMEs financing in Malaysia based on Islamic financing provides some recommendations based on Malaysian SMEs financing successfulness for Indonesian authority to further restructure and enhance their existing financial assistance to the SMEs based on Islamic financing.
\end{abstract}

Keywords: SMEs, Financing, Islamic Financing, Malaysia, Indonesia

\begin{abstract}
Abstrak. Studi membahas tentang akses Usaha Kecil Menengah terhadap pembiayaan keuangan Islam di Malaysia dan keberhasilannya. Inovasi dalam lanskap pembiayaan di Malaysia memberikan manfaat terhadap UKM di negara tersebut dalam mengakses bantuan pembiayaan tanpa harus mengandalkan moda pembiayaan tradisional. Peran pemerintah Malaysia juga tidak dapat dipungkiri dalam upaya mendukung perkembangan UKM melalui berbagai kebijakan. Dalam konteks Indonesia, peran UKM dalam mendongkrak perkembangan ekonomi Indonesia pun tidak dapat dibantah. Secara statistik, UKM di Indonesia mewakili sekitar 99 persen pada semua sektor ekonomi, serta melibatkan partisipasi pekerja hampir 95 persen. Meskipun memiliki kontribusi yang lebih luas, akses terhadap pembiayaan masih menjadi salah satu kendala utama yang menghambat perkembangan UKM di Indonesia. Untuk itu, penelitian ini mengkaji secara kritis kesuksesan UKM Malaysia yang menggunakan pembiayaan Islam, untuk kemudian menjadi rekomendasi bagi pihak berwenang di Indonesia dalam upaya restrukturisasi dan peningkatan bantuan pembiayaan bagi UKM berdasarkan mekanisme pembiayaan syariah.
\end{abstract}

Kata kunci: UKM, Pembiayaan, Pembiayaan Syariah, Malaysia, Indonesia

${ }^{1}$ Department of Economics and Finance, Sunway University, Malaysia.

${ }^{2}$ Faculty of Business, Economics and Accounting, HELP University, Malaysia.

E-mail: ${ }^{1}$ hassanudint@sunway.edu.my 


\section{Introduction}

Malaysia is one of the leading Southeast Asian economies aiming of becoming a nation of high-income status by 2020. Over the years, the Malaysian economy has gone through a dramatic transformation from an economy dependent on agriculture and commodity export to a more diversified and open economy with a much greater global connection. The Real GDP growth rate on average of 6.4 percent per annum since 1970 (OECD,2016), which was crucial for the Malaysian government to address the development and equity agenda. Prior to the implementation of the New Economic Policy (NEP), Malaysia's development policy was mainly focused on enhancing economic growth with a great focus on the export market. The economy achieved a decent average annual growth of 6 percent, but there was an inadequate emphasis on the distributional aspects, causing in socioeconomic inequalities among the ethnic groups with negative social consequences lead to a racial riot in 1969 (Economic Planning Unit,2017). It was after this incident; the Malaysian government decided to introduce the NEP in order to address the socio-economic problems. This policy combined growth aspirations with the main objective of forming a fair, just and unified nation. Unlike other nations where the lower of the income bracket is comprised of ethnic minorities, the Malay majority in Malaysia earns lower incomes despite being more than half of the total population. (Saari, Dietzenbacher, Los, 2015). The NEP was implemented with two key objectives, that is to eradicate poverty regardless of ethnicity and to ensure economic opportunities were available to all Malaysians regardless of background. The importance of SMEs in Malaysia can be traced back to the early 1970s with the implementation of the NEP targeted enhancing people's well-being and addressing the economic disparity of the various races. This is done through restructuring of the society aimed at attaining income parity and employment opportunities for all. The NEP set a restructuring target of 30: 40: 30, whereby 1990, the holdings of the Bumiputeras should reach 30 per cent, other Malaysians 40 per cent and the foreigners 30 per cent, in the context of an expanding economy marked the beginning of a much active participation of Bumiputras in businesses, which includes the formation of micro, small and medium enterprises.

It was evident that the small and medium enterprises play a key role in the economic development, social uplifting and political stability of every country. It is now regarded as a backbone of national economy (Peters \& Waterman, 1982; Amini, 2004; Radam et al., 2008 as cited in Khalique,2011). The successfulness of SMEs in Malaysia contributed by many factors, especially with regard to the 
financial accessibility as the Malaysian authority give high emphasis on Fintech in helping the entrepreneur to raise capital for a start-up the businesses. And, this successfulness is contributed by conventional and Islamic finance.

Given this, the objective of the paper is to discuss the possibility and potential of Islamic finance in Indonesia in providing capital to Small and Medium Enterprise (SMEs) or ventures. Firstly, this research will highlight the successfulness of SMEs in Malaysia then this study will provide some recommendation to the Indonesian authority in developing the progression of SMEs in their country. As evidenced in many works and published economic report, the SMEs is playing an important role in terms of GDP in various socioeconomic aspects. However, the issue of financial accessibility seems to obstruct the development of SMEs in Indonesia. Given this problem, the study will look into how Islamic finance can help in mitigating the issue of financial accessibility and allows active participation of SMEs in Indonesia by considering Islamic finance in terms of financial support.

The remaining structure of the paper is structured as follows; section one will discuss the introduction part followed by second part which discussion on the Malaysian SMEs in general based on available literatures. The third part will focus on the methodology employed in this research, and finally there would be discussion on analysis part with regard to potential of Islamic finance and SMEs in Indonesia

\section{Malaysia's Definition of SME}

SME definition, which was accepted at the 14th NSDC Meeting in July 2013 covers all sectors, namely services, manufacturing, agriculture, construction and mining \& quarrying. The definition is based on two main criteria, namely (i) sales turnover and (ii) number of full-time employees. SMEs in the manufacturing sector are firms with a sales turnover not exceeding RM50 million or a number of full-time employees not exceeding 200. As for the services and other sectors, SMEs are defined as firms with sales turnover not exceeding RM20 million or number of full-time employees not exceeding 75 . The following table provides the definition of category, namely micro, small and medium is as follows: 
Table 1. Definitions of SME in Manufacturing sector

\begin{tabular}{ccc}
\hline Size of firms & Sales turnover(RM) & Number of employees \\
\hline Medium & RM15 million $\leq$ RM50 million & $75 \leq 200$ \\
Small & RM0.3 million < RM50 million & $5<75$ \\
Micro & Below RM 0.3 million & Less than 5 \\
\hline
\end{tabular}

Notes: This table portrays the definition of SMEs in manufacturing sector. The definition differs across medium, small and micro. The source for this table is extracted from the SME Annual Report, 2015/16.

Table 2. Definitions of SME in Services and other sectors

\begin{tabular}{ccc}
\hline Size of firms & Sales turnover(RM) & Number of employees \\
\hline Medium & RM3 million $\leq$ RM20 million & $30 \leq 75$ \\
Small & RM0.3 million < RM3million & $5<30$ \\
Micro & Below RM 0.3 million & Less than 5 \\
\hline
\end{tabular}

Notes: This table portrays the definition of SMEs in service sector and other sectors. The definition differs across medium, small and micro. The source for this table is extracted from the SME Annual Report, 2015/16.

\section{SMEs Development In Malaysia}

There is growing recognition of the important role of SMEs as an economic agent and government have given a high priority to SME development as they strive to achieve sustainable and inclusive growth. The importance of SMEs in Malaysia begins with the implementation of the NEP in 1971 with the objectives of eradicating poverty and improve the welfare of the people and restructuring the society in order to eliminate ethnic economic imbalance. The policy encourages the Bumiputra participation in business, especially by starting in small scale through various government initiatives and programmes. The implementation of Malaysia Industrial Plan and the establishment of the Small and Medium Corp (SME Corp), by the Ministry of International Trade and Industry(MITI) further strengthened the development of SMEs (Ziaul Hoq et al. 2009). In 1992 The National Development Policy (NDP) replaced the NEP, and as stated by Athukorala \& Menon (1999), the NDP consideration was to amend ethnic difference using various agencies which were responsible for the development of entrepreneurship, managerial capability and skills among the Bumiputra. 
In order to encourage and support the SMEs, the government through the Ministry of International Trade and Industry(MITI) established an agency known as Small and Medium Industries Development Corporation (SMIDEC) in 1992. This agency was required to make the SMEs more capable and competitive in the global market. Various programmes and initiatives were introduced to enhance SMEs capability and competitiveness by providing financial accessibility, capacity building opportunities, market penetration, brand development, human capital development, technology and innovation enhancement and advisory services.

The government continues to pay great attention to the development of SMEs decided to establish the National SME Development Council (NSDC) in 2004. This marked the commencement of a new chapter in the SME development in Malaysia. NSDC was entrusted in formulating and implementing strategies for SME development involving all economic sectors, coordinate SME programmes executed by the relevant ministries and agencies and also to the enhancement partnership with the private sector. Among the initiatives carried out by the NSDC comprised of enhancing access to financing, financial restructuring, advisory services, information, training and marketing coordination and a comprehensive SME database to monitor the progress of SMEs across all economic sectors (SME Corp, 2017).

SMIDEC was later appointed by NSDC in 2007 as a single agency to formulate policies and strategies for SMEs and also responsible for coordinating the various programmes across relevant ministries and agencies. In 2009, SMIDEC was rebranded and known as the Small and Medium Enterprise Corporation Malaysia (SME Corporation Malaysia). SMEs needing relevant information and advisory services can now refer to SME Corporation Malaysia, which is done via One Referral Centre (ORC). SME Corp has now become the nation's key organization responsible for developing an innovative, resilient and globally competitive SMEs and also improve wealth creation and social well-being of the nation.

SME Corp. Malaysia was also entrusted in developing and implementing the SME Masterplan (2012-2020), providing the policy direction of SME development in order to achieve a high-income nation status by 2020. It is through this plan the growth of SMEs was accelerated through the implementation of innovation and productivity-related strategies. It was done by fostering a close alliance with relevant industry associations and strategic partners from the public as well as private sectors. The government in its 2017 budget has given special attention to the SMEs and declaring 2017 as the start-up and SME promotion year. A sum of RM70 million was allocated for the SME Masterplan for the purpose of implementing the High 
Impact Programmes. The six High Impact Programmes is summarized in the following table.

Table 3. HIPs of SME Masterplan

\begin{tabular}{|c|c|c|}
\hline $\begin{array}{c}\text { HIP 1: Integration of } \\
\text { Business Registration and } \\
\text { Licensing }\end{array}$ & $\begin{array}{l}\text { HIP 2: Technology } \\
\text { Commercialization } \\
\text { Platform(TCP) }\end{array}$ & $\begin{array}{l}\text { HIP3: ME Investment } \\
\text { Partner(SIP) }\end{array}$ \\
\hline $\begin{array}{l}\text { Create a single registration } \\
\text { point through the interfacing } \\
\text { of the current National } \\
\text { Business Registration System, } \\
\text { that is, MyCoID and the } \\
\text { national Business Licensing } \\
\text { System, that is, BLESS }\end{array}$ & $\begin{array}{l}\text { Establish a national network of } \\
\text { a privately managed platform } \\
\text { to promote innovative ideas } \\
\text { from proof of concept to the } \\
\text { commercialization stage. }\end{array}$ & $\begin{array}{l}\text { Provide early-stage financing } \\
\text { through the establishment of } \\
\text { the investment of investment } \\
\text { companies to invest in } \\
\text { potential SMEs in the form } \\
\text { debt, equity or hybrid of } \\
\text { both. }\end{array}$ \\
\hline $\begin{array}{l}\text { HIP 4: Going Export(GoEx) } \\
\text { programme }\end{array}$ & HIP 5: Catalyst Programme & HIP 6 : Inclusive Innovation \\
\hline $\begin{array}{l}\text { Offer customized assistance } \\
\text { to new exporters and SMEs } \\
\text { venturing into new markets. } \\
\text { Export-ready SMEs can avail } \\
\text { to comprehensive support } \\
\text { assistance. }\end{array}$ & $\begin{array}{l}\text { Create home-grown } \\
\text { champions through a targeted } \\
\text { approach with support in } \\
\text { the area of financing, market } \\
\text { access and human capital } \\
\text { development. }\end{array}$ & $\begin{array}{l}\text { Empower the bottom } \\
40 \%(\mathrm{~B} 40) \text { of the income } \\
\text { group to leverage on } \\
\text { innovation through the } \\
\text { transformation of the rural } \\
\text { community through the } \\
\text { hand-holding approach. }\end{array}$ \\
\hline
\end{tabular}

Notes: This table shows the High Impact Programmes for SMEs in Malaysia. Altogether, there are 6 HIPs under the SMEs master plan. The details of this were extracted from the SMECorp, 2017 published report.

In this budget, the government also announced a reduction in the corporate tax rate from 19 percent to 18 percent for the first RM500,000 for SMEs and the incremental revenue would also be subject to a lower tax rate, which will be enjoyed by all businesses (Nee, 2016). The government has also allocated a sum of RM350 million to assist and support SMEs to access to foreign market, whereby RM130 million was allocated for promotion purpose to be carried out by MATRADE, SME Corp. Malaysia and MIDA. RM200 million allocated for financing and insurance credit purpose providing a coverage up to RM1 billion by EXIM Bank. A 2 percent rebate amounting to RM 20 million was allocated for the scheme of "Syarikat Jaminan Pembiayaan Perniagaan" (SJPP).

In order to enhance the income of B40 households, RM290 was allocated to encourage the development of B 40 entrepreneurs under various programmes, 
such as, Mobileprenuer Programme by GIATMARA (RM30 million), Agropreneur programme (RM100 million), eUsahawan and eRezeki programmes under MDEC (RM100 million) and RM5,000 per taxi driver to purchase new vehicles with individual taxi permits given (RM60 million). To encourage Bumiputera entrepreneurs a total of RM 1.4 billion was allocated under various government agencies programmes, such as SME Bank (RM100 million), Amanah Ikhtiar Malaysia (RM100 million), TEKUN (RM300 million), PUNB (RM200 million), MARA (RM120 million) and TERAJU (RM600 million). As for the Indian and Chinese entrepreneurs a sum of RM200 million and RM90 million was allocated respectively. As for the women entrepreneurs, a total of RM2 billion was allocated for I-KIT, I-KeuNita and Women Career Comeback programmes (Ministry of Finance Malaysia,2017).

SMEs is also important to the economies of Asia, where it constitutes 98 percent of all enterprises and 66 percent of the national labor force on average during 2007-2012 (Yoshino \& Taghizadeh-Hesary, 2016). Taking into account the significance of SMEs the Association of Southeast Asian Nations (ASEAN) establishes ASEAN SME Agencies Working Group (SMEWG) to develop a Strategic Action Plan for SME Development (SAPSMED 2016-2025). The aim of the plan is to enhance the engagement of SMEs and to make the SMEs globally competitive and innovative by 2025. As reported in the SME Annual Report, 2016, the goal of this action plan is to promote technology, productivity and innovation, increase access to finance, enhance market access and internationalization, enhance the policy and regulatory environment, and promote entrepreneurship and human capital development.

The group has also carried out projects, such as the Digital Economy Action Plan and Work Agenda (DEAP), organizes workshops in order to improve internet accessibility of SMEs. Access to the Internet Economy. It provides opportunity for SMEs to exchange information on the challenges they face and also highlights best practices for supporting SME access and raises awareness of private-sector efforts to integrate SMEs into global and regional markets. The further opportunity of SMEs' access to global markets was created in 2016, through APEC initiative of funding the 'New Era of Growth for APEC SMEs through Online-to-Offline (O2O) Business Models' project in cooperation with top e-commerce organizations such as eBay, Amazon and Alibaba. 


\section{SMEs Socio-Economic Contributions}

SMEs play a vital in the economic growth of Malaysia (Chelliah, Sulaiman et al. 2010; Hashim 2007; Othman, Sulaiman et al. 2008, as cited in Madanchian M., et al., 2015). Apart from creating job opportunities, SMEs also contributes to the development of big and multinational corporations (Aman \& Tahir, 2011). The SME development framework was established to enhance the overall contribution of SMEs to the Malaysian economy from 2015 to 2020. SME development framework vision is to create globally competitive SMEs to enhance wealth creation and contribution to social well-being. The SME development framework goals consist of increasing business formation, increasing the number of high growth and innovative firms, raise productivity, and intensifying formalization. Six focus areas were identified comprising of enhancing innovation and technology adoption, human capital development, accessibility to financing and market, legal and regulatory environment, and infrastructure to achieve the goals, and eventually the vision of the framework. Acquiring of reliable database, proper monitoring and evaluation, effective coordination and effective business services through proper and effective institutional supports needed to execute the action plans effectively.

As a result, SMEs progress well over the years with its contribution to GDP increasing from 29.6 percent in 2005 to 36.3 percent in 2015 (SME Corp, 2017). SME GDP grew moderately by 6.1 percent in 2015 compared with the underlying growth of 7.9 percent recorded in 2014 . The growth was nevertheless higher than the overall GDP of the country by 5.0 percent. The aim of the $11^{\text {th }}$ Malaysian Plan (2015-2020) was to have the SMEs to contribute 41 percent of the country's GDP and to constitute about 97.3 percent of total business establishments and provide 65 percent of the total employment and 23 percent of the total exports by 2020 (Planning 2015).

With the economy enjoying an encouraging growth and also through a development model emphasizing on equitable growth, including increased participation of the Bumiputera (ethnic Malays and indigenous groups) in the modern economy, resulted in a gradual decline the high levels of income inequality inherited at independence. The Gini coefficient for Bumiputera during the inception of NEP 1971 was 0.466 , and it has raised to 0.506 in 1976 but has declined in 1979 to 0.468 , and it continued to decline until the year 1989 at 0.429 . NEP came to an end in 1990 and National Development Policy (NDP) was introduced and since then, there have been fluctuations in the Gini coefficient for Bumiputera. Starting at 0.442 for 1992 , and it decreased to 0.441 in 1995 , then increased back to 0.448 in 1997, and to 0.433 in 1999 (Economic Planning Unit, 2017). 
In 2010, the Malaysian Prime Minister Najib Razak introduced a new economic plan, known as the New Economic Model (NEM) aiming at shifting the affirmative action from ethnic-based to need-based with the aspiration of becoming a high-income nation by 2020 (NEAC, 2010). The policy intended to make the nation to become more competitive and also investor-friendly. The main objectives of the NEM are "high income, sustainability and inclusiveness". The Gini coefficient is 2009 for Bumiputra was 0.440, Chinese 0.425, Indians 0.424 and others 0.495. The Gini coefficient for the Bumiputra and Chinese has decreased after 2 years of the implemented of the NEM. As for India, the Gini coefficient rose from 0.424 to 0.443 . However, the latest data in 2014 shows that all of the ethnic groups have narrowed down the gap and reduced the Gini coefficient (Economic Planning Unit,2017).

The Millennium Development Goals Report (MDGR, 2015) indicates that Malaysia has achieved most of the goals and objectives. Absolute poverty has been largely eradicated. The benefits of development have been felt at the national, regional, state levels, and in many cases, the community and individual levels. Remarkable progress in the country is observed in many areas, as revealed by the Millennium Development Goals Report for Malaysia in 2015. The reduction of absolute poverty (based on the national poverty line, which is twice higher than the MDG conventional of USD1.25 per capita) from 16.5 percent in 1990 to 0.6 percent in 2014. With the drastic decline in absolute poverty, the government has turned its attention to the vulnerable part of the population, the bottom 40 (B40) household income group. These groups comprise a large and heterogeneous group of 2.7 million households in 2014. The focus, thereby moved towards equitable economic participation, with more support for the bottom 40 percent of households by income (B40).

\section{SMEs Challenges}

Most of the business establishment all around the world is dominated by SMEs. As in Malaysia, 98.5 percent of the total business establishments of 907,065 are SMEs. The micro-business in Malaysia constitutes about 76.5 percent $(693,670), 21.2$ percent $(192,783)$ are small businesses and 2.3 percent $(20,612)$ are medium enterprises). The focus of these SMEs was in the services sector increased 89.2 percent or 809,126 establishments with largest subsector in the distributive trade. Another 5.3 percent of the total SMEs $(47,698)$ were in the manufacturing sector, followed by 4.3 percent in the construction sector $(39,158)$ and 1.1 percent $10,28)$ in the agricultural sector and the remaining 0.1 percent $(865)$ in the mining 
and quarrying sector (SME Corp, 2017). It is recognized, however, that SMEs in many countries face severe and numerous challenges. According to Ahmad \& Seet (2009), apart from the SME huge establishment, but the failure of SMEs in the first five years is also extremely alarming. It was reported that in Malaysia, the failure rate was as high as 60 percent (Nordin, Hamid \& Woon, 2011; Chong, 2012; Husin $\&$ Ibrahim, 2014). The failure rate continues to rise even with various government assistance and programs targeting the new entry SMEs (Chong, 2012).

Beh (2013) highlighted the key factor for SME failure was the owners unaware of the business challenges in terms of financial accessibility and management ability and skills. The funds provided by the government or any other sources are used without proper records and future plans. Ting (2004) identified many challenges encountered by the Malaysian SMEs and the five key issues identified through various researches are the financial constraints, inadequate human resource developments, inability to adopt more advanced technology, asymmetric information on potential markets and customers, and increasing global competition from economic integration. He also concluded that there is a high possibility of SMEs failing if these challenges are not addressed making them less competitive in the new rapidly developing world of globalization

Similarly, Wang (2003) pointed some of the challenges facing SMEs in a globalized environment, namely, financial constraints, low productivity, lack of managerial capabilities, access to management and technology, and a heavy regulatory burden. Agyei-Mensah (2010), confirmed that the most common problems of SMEs are related to inadequate capital, cash flow and inventory control.

A study done by Mckinsey, 2011 shows a productivity gain of 11 percent among SMEs that use the web. In addition, a web-based entrepreneurship foster creativity and innovation and competition. Although, there are many benefits of ICT, most businesses in Malaysia, in particular SMEs are still slow in adopting ICT due to financial constraints, inadequate technical knowledge, and high cost of the technical team and soft applications. Only 20 percent of SMEs in Malaysia uses ICT extensively in their daily operation.

It can be concluded that Malaysian SMEs continues to face domestic and external challenges that despite these governmental programmes hindering their resilience and competitiveness. They include:

- Difficulty in getting funding from the financial institutions and government or funds are given with a high interest rate due to the high risk and lack of financial transparency. A lack of human capital is the most significant challenge facing 
Malaysian SMEs. It is often too expensive for SMEs to employ a professional and competent workforce.

- The level of competition faced by SMEs in the domestic market has intensified due to the entry of new international competition resulting from the economic integration

- A lack of access to better technology and ICT, which hinders more efficient and productive business operations.

- A high level of bureaucracy in government agencies hinders efficient SME business development operations.

- A low level of research and development expenditure.

\section{Methodology}

Under the methodology section, firstly, there will be a discussion of the research goal followed by second discussion on the sampling procedure together with data collection.

\section{Research Goal}

The purpose of this study is to highlight the successfulness of SMEs in Malaysia in accessing financial assistance from Islamic banking. By looking into Malaysian successfulness, then this study will provide some recommendation to the Indonesian authority in developing the progression of SMEs in their country. As evidenced in many literatures and published economic reports, the SMEs is playing an important role in terms of GDP in various socio-economic aspects. However, the issue of financial accessibility seems to obstruct the development of SMEs in Indonesia. Given this problem, the study will look into how Islamic finance can help in mitigating the issue of financial accessibility and allows active participation of SMEs in Indonesia. During the development of this paper, the available qualitative and quantitative methods of economic research were used including comparative analysis and graphical illustration methods in understanding the said issue in more vibrant way.

\section{Sample and Data Collection}

As for sample and data collection, the materials are firstly collected from the available literature review with regard to the SMEs and financial accessibility in Malaysia and difficulties of SMEs in Indonesia. The literatures are available in 
the various source of engines especially in journal database such as Science Direct, Springer and many other. As for Indonesian SMEs details, this research uses the data obtained from World bank website, Marsh and McLennan report, PwC report, Ministry of Cooperative and Small Medium Enterprise, Otoritas Jasa Keuangan (OJK), Bank Indonesia website. Basically all these as stated above are based on secondary data. Once done with this scope, from this knowledge, the paper will explore more on the potential of Islamic finance in the context of Indonesia by referring to Malaysia as a reference and provide some recommendation to the Indonesia authority in solving the said issue and enhance further the development of SMEs in their country.

\section{Analysis and Results}

The section on literatures divided into several parts; firstly, it will introduce the overall successfulness of SMEs financing schemes implementation in Malaysia. Later on, the discussion will continue with the Islamic Banking System (IBS), Practices and contribution towards SMEs in Malaysia. The third section reveals about the Indonesian SMEs and its challenges followed by the Islamic banking (IB) and its involvement in SMEs of Indonesia. The last section will discuss the recommendation to the Indonesian authority based on Malaysian SMEs successfulness and the potential of Islamic finance.

\section{The successfulness of SMEs financing schemes implementation in Malaysia}

The report of SME development published by the SMECorp in 2016 reveals that the financial institutions serve as a primary source of fund to the financial accessibility by the SMEs in Malaysia. At the end of 2015, the total financing to SMEs by financial institutions recorded a growth of 14.6 percent which was valued at RM274.5 billion that extended to 729,983 SME accounts. The share of SME finance from the entire total business financing had incremented to 46.6 percent in 2015 compared with 2014 where the total percentage was just 43.8 percent. The loan approval remains at above 80 percent and total financing rose to RMRM285.5 billion as of June 2016.

The Credit Guarantee Corporation Malaysia Berhad (CGC) is considered as the main pillar in providing guarantees to the SMEs in letting the SMEs access to the financial accessibility from the financial institution. The CGC progressing well in leverage part for SMEs and creating opportunity for the new and existing SMEs by supplying them direct financing schemes to starts-up and encourage women 
entrepreneurship as well as involvement in the green technology and enterprise the intellectual property. Furthermore, the CGC is not only limited to the loan accessibility and guarantee but also provide advisory services with regard to the business development, credit information and credit rating with cooperation from Credit Bureau of Malaysian Sdn Bhd. From 1972 till 2015, CGC had provided financing to more than 437,00 businesses which were valued at RM59 billion. In 2016, this institution estimated the loan approval for about 8,650 accounts valued at RM4 billion. Case in hold, CGC has also established new ways in processing the loan and disbursement of funds such as Portfolio Guarantee (PG) where the banks are allowed to choose the customers in accordance with criteria determined and loan process application on a portfolio basis. In doing so, it enabled both CGC and the banks to speed up the approval and disbursement of loan to the SMEs.

The successfulness of CGC further continues by the establishment of two new schemes for specific groups, namely:

i) BizWanita -i

This financing scheme is designed for women entrepreneur who owned the business. The purpose of this scheme is to minimize the gaps for women entrepreneurs in terms of accessibility. Two months after the introduction which was on October 2015, CGC had approved RM10 millions of financing to 76 SMEs. The establishment of this scheme has bridge the gap between gender equality between man and women entrepreneurs effectively.

ii) Special Assistance Scheme-I (SAS -i)

Under this scheme, the entrepreneur can recover back their business loss due to the natural disaster such as floods, tsunami and earthquake. The funds then can be utilized for buying new assets, as well as for working capital. The financing scheme is based on the Murabahah concept, and the coverage is ranged from RM20,000 till RM200,000 and the tenure is 5 years. The allocated fund for this scheme by government is RM35 million.

Furthermore, in 2015, the government of Malaysia invested RM4.4 billion to accelerate the financing to the SMEs via 36 programmes. The selected programmes include:

i) Soft Loan Scheme for SME (SLSME)

This scheme is under the Ministry of International Trade and Industry (MITI) with the collaboration of Malaysian Industrial Development Finance Berhad (MIDF). This scheme specifically to help existing and new start-up companies to raise working capital, financing fixed assets, relocations of business operation 
and to improve SMEs competitiveness. In the year of 2015, there were RM174.5 million approved for about 187 SMEs comprises of many industries.

ii) Dana Pinjaman Perniagaan Kecil dan Sederhana (PKS)

Under this scheme, the entrepreneur benefits from various activities implemented in this scheme such as Dana 1-SME, Tabung Usahawan Siswazah, Dana Usahawan Negeri Terengganu, Skim Modal Asas, Skim Pembiayaan Ekonomi Desa (SPED), Program Usahawan Agro-Based, and the ASEAN Japan Development Fund. As for the initial stage, there were 87 entrepreneurs selected for various programme under this scheme and successfully benefited from the socio-economic point of views.

iii) Sharia Compliant SME Financing Scheme (SSFS)

The MITI collaborated with SME Corp. Malaysia permitted discount more than RM20 million to 874 SMEs under the SSFS scheme. Under this, the government will pay 2 percent of the financing charges imposed by Islamic banks. Through the Business Accelerator Programme (BAP), SMEs is also ratified extra financing valued to RM183.2 million in the form of loan and grant for more than 879 SMEs.

iv) Dana Modal Teroka

The Ministry of Finance (MOF) together with Kumpulan Modal Perdana Sdn. Bhd has spent RM10.9 million in giving financing for venture capital especially in the electrical and electronics-related businesses (E\&E). In 2015, two companies have successfully invested and developed 11 intellectual property (IPs) with 24 knowledge-based employees.

v) Program Sokongan Bahan Mentah kepada Usahawan Kayu Bumiputera

The Malaysian Timber Industry Board (MTIB) with the cooperation of the Ministry of Plantation Industries and Commodities (MPIC) able to sourcing out RM67.2 million worth of contract sales in 2015. From the RM67.2 million, RM10.2 million was allocated for programme which has benefited 62 Bumiputera entrepreneur in the timber industry.

vi) Business in Transformation (B.I.T.)

In producing new entrepreneur, Ministry of Domestic Trade, Cooperative and Consumerism (KPDNKK) established a programme called Business in Transformation (B.I.T) wherein 2015, the programme channeled RM2.3 million to 324 SME entrepreneurs which have resulted in job creation by 1 , 557 new job opening. 


\section{Islamic Banking System (IBS), Practices and contribution towards SMEs in Malaysia}

By definition, IBS can be defined as a banking system that their operations and activities are strictly based on the Sharia rules and principles. From 1960, Islamic banking (IB) recorded well development and progression, although the IB still in pioneering bank compared to the conventional banking who had established more than 420 years ago. One of the unique characteristics of IB is the concept of profit and loss (PLS) scheme where the transactions are done via Mudharabah (profit - sharing) and Musharakah (joint-venture). Basically, under this scheme, all assets and liabilities of lenders are assimilated, and with this type of arrangement, Islamic banks will lend on a longer-term basis to support the projects that have higher risk higher return characteristic. Subsequently, it will promote economic growth. However, as per scholar views, they recommend profit/loss sharing scheme over other trading modes, Murabahah is preferred in this context and has been extensively used by majority of IB due to its permissibility. Furthermore, under Murabahah financing, the buy and sell activities with equal instalment is flexible and easier to understand, administer and monitor (Suzuki \& Uddin, 2016).

The literature evidence by Kessler et al. (2007) mentioned that SMEs encourages entrepreneurship, and by expanding the assistance to SMEs will result in economic expansion under the landscape of IB. Dhumale and Sapcanin (1999) found that IB schemes such as Murabahah, Mudharabah and Qardhul Hasan are the tools that mostly suited with SME requirement. Apparently, Qardhul Hasan, Murabahah and Ijarah financing flexible in usage wise and easy to implement in determine the capital needs (Qardhul Hasan), equipment and assets (Murabahah) and Leasing (Ijarah) for SMEs (World Bank-IDB, 2015). Undeniably, the schemes such as Mudharabah and Musharakah seem to have a higher potential in contributing significantly towards the development of SMEs as it satisfying the concept of risk-sharing. Theoretically speaking, various financial schemes can fit for various purposes but is subject to the risk-profiles of the SMEs. Case in hold, in 2003, the study by Ismail and Razak shows that 95 percent of all financing in SME are approved based on Ijarah, Bay Bithaman Ajil, and Murabahah financing schemes. This research actually looking at all the pattern of debt-equity financing for SMEs financing that taking place from 1993 to 1997 . The study concluded that SMEs prefer to select debt financing instead of equity financing to set-up or expand their businesses. Manan et al. (2011) also postulate that majority of Malaysian SMEs choose debt financing like Murabahah, Bay Bithaman Ajil and Ijarah as sources of external capital. 
Basically, the philosophical basement of Islamic finance is purely depending on economic and social development, including the part called financial inclusion which is called unbankable of the society like SMEs. The financial inclusion can be solved by Islamic finance which was based on asset-based and equity-based, thus it can serve as an alternative to conventional financing (financial exclusion). As per discussion above, it is very clear that Islamic banking incorporates the risk-sharing features and well link of credit to collateral that is ensemble for SMEs in promoting the comprehensive economic growth. In Malaysia, the assistance to allow for the best financial inclusion by the SMEs is channeled via two main types of financing which are based on Islamic way, namely (i) asset-based and (ii) equity-based. With this approach, the financing issue, especially for the SME, is tackled in an appropriate way. Under the asset-based, Islamic finance will ensure the transaction is fulfilling the requirement of real economic activity with thorough close to financial linkage to the financial asset. In contrast, equity-based financing is a profit and loss sharing between financial providers and entrepreneurs for their interest business at initial stage. This is suitable for SMEs who needs equity financing for their ventures or businesses.

Figure 1. Financing Availability for SMEs under Islamic Financing

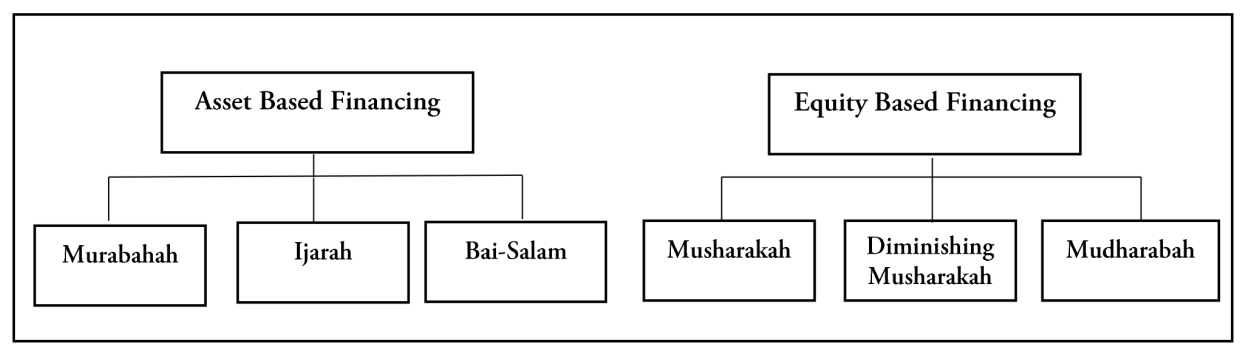

Notes: This figure shows the availability of financing under Islamic financing for SMEs in Malaysia. It is divided into two categories, namely, (i) asset-based financing and (iii) equity-based financing.

The existence of these type of financing to the SMEs and consistent with the Sharia principle have been recognized by various parties, especially policymakers in many countries. The OIC, Organization of Islamic Cooperation placed high importance to the development SMEs and developed various policies to further enhance the development of SMEs through active usage of Islamic financial product which is more linked to the real economic activity. In doing so, it allowed SMEs in member countries to tap into rapidly growing pool of Sharia-compliant funds. 
Undeniably, the role of General Council for Islamic Banks and Financial Institutions together with the Islamic Development Bank (IDB) keeps researching and introduce various innovative financing that can accelerate the growth of SMEs in worldwide and promoting the role of Islamic finance in social finance aspect.

Further explanation of the availability of Islamic SMEs financing in Malaysia, which are based on asset-based and equity-based are given in table 4:

Table 4. Summary of Islamic SMEs Financing in Malaysia

\begin{tabular}{|c|c|c|c|}
\hline $\begin{array}{c}\text { Islamic Asset } \\
\text { - Based } \\
\text { Financing }\end{array}$ & Description & Advantages for SMEs & $\begin{array}{l}\text { Practiced by Islamic } \\
\text { Banks } \\
\text { (Selected Banks), in } \\
\text { Malaysia }\end{array}$ \\
\hline Murabahah & $\begin{array}{l}\text { This financing is an } \\
\text { agreement between } \\
\text { financial providers } \\
\text { and clients where the } \\
\text { financial provider buys } \\
\text { the assets as per client } \\
\text { requirement and then } \\
\text { sell them to the client as } \\
\text { cost-plus mark-up. It is } \\
\text { usually paid in monthly } \\
\text { installment. }\end{array}$ & $\begin{array}{l}\text { The financing usually } \\
\text { fixed during the } \\
\text { financing period. } \\
\text { - The client will know } \\
\text { all the details related } \\
\text { to the price and } \\
\text { mark up and highly } \\
\text { transparent. } \\
\text { - Suitable for short-term } \\
\text { financing. } \\
\text { - The management } \\
\text { of SMEs remain } \\
\text { independent } \\
\text { - Not much issue on } \\
\text { collateral. }\end{array}$ & $\begin{array}{l}\text { - HSBC Amanah } \\
\text { - SME banks } \\
\text { - Maybank Islamic } \\
\text { - Kuwait Finance } \\
\text { - } \text { OCouse (KFH) } \\
\text { - OCBC Al-Amin }\end{array}$ \\
\hline Ijarah & $\begin{array}{l}\text { This is a transaction that } \\
\text { dealings with leasing } \\
\text { based activities. Under } \\
\text { this, one party leases an } \\
\text { asset to be utilized by } \\
\text { a client for agreed time } \\
\text { period, and appropriate } \\
\text { fees need to be paid by } \\
\text { client. Other types of } \\
\text { Ijarah would be Ijarah } \\
\text { Wa Iqtina where the } \\
\text { financier leases assets to } \\
\text { clients for specified rental } \\
\text { charges, while only one } \\
\text { of the parties buys or sells } \\
\text { the assets at the terminal } \\
\text { period of lease. }\end{array}$ & $\begin{array}{l}\text { Allowing financing, } \\
\text { although with lesser } \\
\text { collateral and credit } \\
\text { history. This is because } \\
\text { the lessor can retain } \\
\text { back the lease assets in } \\
\text { the case of default. } \\
\text { - This financing is } \\
\text { suitable for SMEs for } \\
\text { the medium and long } \\
\text { term period. } \\
\text { Not much } \\
\text { documentation } \\
\text { processes involved. }\end{array}$ & $\begin{array}{l}\text { - } \text { SME Bank } \\
\text { - } \text { Mank Islam } \\
\text { Al- Ansia Berhad, SME } \\
\text { Financing } \\
\text { - Maybank Islamic } \\
\text { - OCBC Al- Amin } \\
\text { - Bank Muamalat }\end{array}$ \\
\hline
\end{tabular}




\begin{tabular}{|c|c|c|c|}
\hline Bai-Salam & $\begin{array}{l}\text { This is a forward sale } \\
\text { contract where the } \\
\text { advance payment is paid } \\
\text { for commodities which } \\
\text { going to be delivered } \\
\text { in the future date. This } \\
\text { is especially for the } \\
\text { agricultural product. } \\
\text { Basically the Salam } \\
\text { contract can be used } \\
\text { to financing working } \\
\text { capital for SMEs. }\end{array}$ & $\begin{array}{l}\text { Provide working } \\
\text { capital financing, } \\
\text { which is based on } \\
\text { Sharia complaint. } \\
\text { - Usually benefits to } \\
\text { those SMEs involved } \\
\text { in agricultural } \\
\text { business. } \\
\text { - Preferably useful for } \\
\text { short-term financing. }\end{array}$ & $\begin{array}{l}\text { - SME Bank } \\
\text { - Bank Muamalat }\end{array}$ \\
\hline
\end{tabular}

\begin{tabular}{|c|c|c|c|}
\hline $\begin{array}{c}\text { Islamic } \\
\text { Equity- } \\
\text { Based } \\
\text { Financing }\end{array}$ & Description & Advantages for SMEs & $\begin{array}{c}\text { Practiced by Islamic } \\
\text { Banks } \\
\text { (Selected Banks) in } \\
\text { Malaysia }\end{array}$ \\
\hline Musharakah & $\begin{array}{l}\text { In this financing, the } \\
\text { partnership agreement } \\
\text { made by two or more } \\
\text { than two parties where } \\
\text { all involved parties will } \\
\text { supply the capital to a } \\
\text { joint venture to share } \\
\text { its profit or losses. The } \\
\text { profit is distributed } \\
\text { among parties based } \\
\text { on agreed proportion } \\
\text { and ratio. However, the } \\
\text { losses must be borne by } \\
\text { parties with respect to } \\
\text { their capital contribution }\end{array}$ & $\begin{array}{l}\text { - Sharia-compliant as } \\
\text { it is purely based on } \\
\text { profit and loss sharing. } \\
\text { - Possibility to obtain } \\
\text { a higher percentage } \\
\text { of profit than } \\
\text { entrepreneur capital } \\
\text { contribution. } \\
\text { - SMEs who are looking } \\
\text { for long - term } \\
\text { financing may go for } \\
\text { this type of financing. }\end{array}$ & $\begin{array}{l}\text { - SME banks } \\
\text { - Bank Islam } \\
\text { Malaysia Berhad } \\
\text { - HSBC Amanah } \\
\text { - Kuwait Finance } \\
\text { House (KFH) } \\
\text { - Bank Muamalat }\end{array}$ \\
\hline $\begin{array}{l}\text { Diminishing } \\
\text { Musharakah }\end{array}$ & $\begin{array}{l}\text { This type of financing is } \\
\text { a contract or agreement } \\
\text { where the entrepreneur } \\
\text { agreed to buy the share } \\
\text { of investment of other } \\
\text { partners over time until } \\
\text { the entrepreneur owns } \\
100 \% \text { of the venture. }\end{array}$ & $\begin{array}{l}\text { - The profit and loss } \\
\text { sharing is based on } \\
\text { market rate. } \\
\text { - Possibility of retaining } \\
\text { the SMEs or for the } \\
\text { start-up businesses } \\
\text { over long -run. } \\
\text { - The advantage in } \\
\text { terms of bridge the } \\
\text { gaps of financing, not } \\
\text { giving up equity over } \\
\text { medium to long term. }\end{array}$ & $\begin{array}{l}\text { - Al-Huda CIBE } \\
\text { - Affin Islamic Bank } \\
\text { - Bank Islam } \\
\text { Malaysia Berhad } \\
\text { - Kuwait Finance } \\
\text { House(KFH) } \\
\text { - CIMB Islamic } \\
\text { Bank }\end{array}$ \\
\hline
\end{tabular}




\begin{tabular}{|c|c|c|c|}
\hline Mudārabah & $\begin{array}{l}\text { The partnership } \\
\text { agreement between } \\
\text { the supplier of fund } \\
\text { and an entrepreneur } \\
\text { who is acting as a fund } \\
\text { manager. In the case of } \\
\text { profit, the distribution } \\
\text { of profit will be } \\
\text { taking place as agreed. } \\
\text { However, if its loss, } \\
\text { it is borne by capital } \\
\text { provider. }\end{array}$ & $\begin{array}{l}\text { - Based on profit } \\
\text { sharing only. } \\
\text { - There is no need to } \\
\text { contribute fund to the } \\
\text { venture. } \\
\text { - Possibility to bargain } \\
\text { the profit distribution } \\
\text { ratio. } \\
\text { - Suitable for long - } \\
\text { term SMEs financing. }\end{array}$ & $\begin{array}{l}\text { - } \text { CIMB Islamic } \\
\text { Bank } \\
\text { - } \text { RHB Islamic } \\
\text { - } \text { SME Banks } \\
\text { - } \text { Kuwait Finance } \\
\text { House(KFH) }\end{array}$ \\
\hline
\end{tabular}

Notes: This table shows the Islamic finance that is available to the Malaysian SMEs. There are two categories, namely, (i) asset-based financing and (ii) equity-based financing.

\section{Indonesian SMEs and its challenges}

The role of SMEs and entrepreneurs in Indonesia undeniably important in boosting up the growth of the Indonesian economy. Looking at the fact given by Bellefleur in the USAID report in 2012, SMEs occupied almost 99 percent in economic sectors in Indonesian market and involved labor participation almost 95 percent. In terms of GDP contribution, the SMEs is account for 57 percent, but unfortunately it represents only 0.24 percent of the population from the entire population in Indonesia. As for definition and categories of SME, the below table provide an overview of it.

Table 5. Categories of SMEs in Indonesia

\begin{tabular}{ll}
\hline Categories & Description \\
\hline Micro Industry & $\begin{array}{l}\text { Net assets more than IDR50,000,000 } \\
\text { Net sales revenue of IDR300,000,000 }\end{array}$ \\
\hline Small Industry & $\begin{array}{l}\text { Net assets more than IDR50,000,000 to IDR500,000,000 } \\
\text { Net sales revenue of IDR300,000,000 to IDR2,500,000,000 }\end{array}$ \\
\hline Medium Industry & $\begin{array}{l}\text { Net assets more than IDR500,000,000 to IDR100,000,000,000 } \\
\text { Net sales revenue of IDR2,500,000,000 to IDR50,000,000,000 }\end{array}$ \\
\hline
\end{tabular}

Notes: This table shows the definition of SME in the context of Indonesian and its classifications. There are three categories includes micro-industry, small industry and medium industry.

According to the statistics shown by Ministry of Cooperatives and SMEs in 2012 at Indonesia, the SMEs participation rate has spread to various industry consists 
of agriculture, mining, livestock, electricity, construction trading, hoteling, real estate and many others. Not only that, as evidenced in the literature, SMEs in Indonesia have robust impact on the next export of Indonesia. According to Nugroho (2012), the contribution of SMEs export equivalent to 15.81 percent of total net export in 2010 to 2012, among the popular export area are handicraft, fashion and accessories, furniture, food and beverages and finally beauty product. Due to diversity in terms of businesses, the SMEs plays an important role in regional development as well, particularly in rural territorial. The performance of SMEs compared with corporates seem relatively low in terms of contribution to the GDP. There are 5,000 corporates involved in businesses with the percentage of contribution about 38 percent to the GDP compared with 700,000 SMEs altogether involved in various businesses but only contributes 22 percent to the Indonesian GDP. The details of employees and outputs in Indonesian enterprises in 2013 are disclosed in Figure 2 below:

Figure 2. Enterprises, Employees and GDP of Indonesia

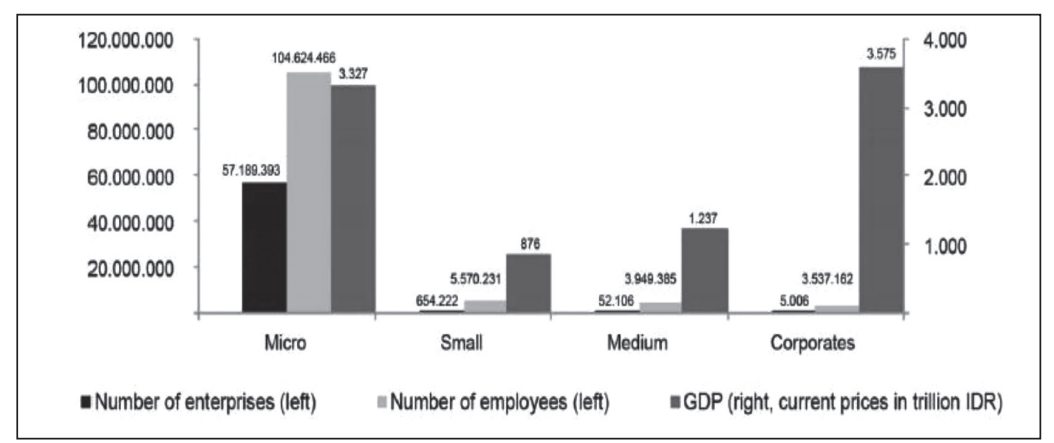

Notes: This figure reveals the details of the number of enterprises, employees and its contribution to the Indonesian GDP.

The development and growth of SMEs in Indonesia can be classified into four parts as per illustrated by Nugroho (2012), namely:

i) Firstly, the flexibility involves to SMEs where the SMEs become a subcontractor to the larger firms and obtain their own market to survive. Given such flexibility it allowed the SMEs to maintain the business and survive although the economic crisis occurred.

ii) Looking at SME growth, it depends on the maturity stages of the SMEs. Usually the SMEs in early stages, the starting point would be like household industries and later become manufacturers in coming stages. 
iii) The increase in income for individuals have created new market for SMEs as the customer demand pattern encounter the shift in paradigm to more sophisticated and innovative product. With this transformation, the growth level of SMEs is also expanding and allow for competition among the SMEs which subsequently lead to further innovation and enhancement in terms of product offerings.

iv) Finally, the growth of SMEs in urban areas is comparatively faster than in rural areas. This perhaps due to the fact wherein the urban areas, the population density is higher that lead to greater demand for the product offered compared to those who are in the rural areas. In terms of business accessibility, the SMEs in urban are dominant because of rapid development that takes place in urban areas.

Based on a report published by Marsh and McLennan (2015) reported that Indonesia has abnormally higher microenterprise segment compared other emerging markets but smaller in terms of SMEs. The finding by Marsh and McLennan disclosed that in Indonesia there are 358 microenterprises but only 4.4 SMEs per 1000 adults. In comparison with Malaysia, which has less microenterprise but more SMEs than Indonesia. It means only 1 percent of Indonesia microenterprises able to grow consistently to maintain the SME size at any stage. More than 90 percent of these enterprises have limited capacity for accessing financial support. In one of research conducted by Marsh and McLennan postulate that 44 percent of microenterprise is located in rural Indonesia, do not have full loan accessibility. From those unable to get financing, 35 percent indicated that they need fund but no accessibility while another 30 percent said will borrow the fund in nearest future.

Figure 3. Comparison of No. of Micro and SMEs Per 1,000 Adult Population Across Emerging Asian Countries in 2014

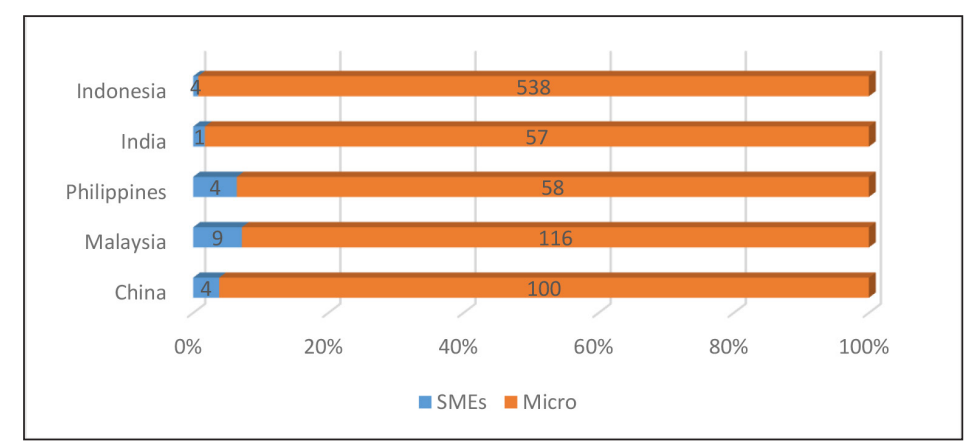

Notes: This figure shows the statistics on the No. of Micro and SMEs Per 1,000 Adult Population Across Emerging Asian Countries in 2014. The data were obtained from the World Bank website for the year 2014 . 
As common in many developing countries, Indonesian is in trouble as well when it comes to SMEs development. The problem of "missing middle" has haunted the progression of SMEs as majority of banks in Indonesian need to focused and fulfill the need from smallest and largest businesses. The financial institutions tend to help the well-established and larger firms compared to those who are newly entering into the market. In other words, the banks become too selective when providing financing to the businesses. Due to this issue, the SMEs are far behind in terms of its development and productivity. With this issue, apparently, the SMEs in Indonesia are continuing to grow at faster pace, and there is always a positive outlook where the SMEs will be a significant contributor to the economic progress in the coming years. Not only that, the Indonesian government also has implemented various strategies for making sure the SMEs able to access finance easily. Such policy like low tax rate (12 percent) for the SMEs that achieve gross income less than IDR4.8billion. This tax rate seems to be comparatively less with other ASEAN countries (on average 15 percent).

Furthermore, the Indonesian government was also providing funding to SMEs with low-interest rate for low-risk profiles of SME to further accelerate the development of SME. Most recently, the government introduced few measures to soften the financial burden such the annual interest rates for subsidized people's business credit (KUR) minimized to 9 percent from 22 percent before. The President of Indonesia, Jokowi Widodo has promised to lower down to 7 percent by end of 2017. Together with this, banks are on track as well in helping the progression of SMEs, for instance, Bank Rakyat Indonesia (BRI) has allocated largest fund for microentrepreneur, IDR202.58 trillion and this fund will grow 15 percent from 2015 onwards. Case in hold, UOB Indonesia, has shown interest to launched five new SMEs in Jakarta, Semarang, Central Jawa, Surabaya and East Java by the end of 2017.

Although various policies are implemented, the growth of SMEs not up to standard. The report published by the Price Water Cooper House ( $\mathrm{PwC})$ in 2017 revealed that expected lending growth for SMEs is just 12 percent compared with other lending and it is relatively less. See the figure below for more information. 
Figure 4. Estimated Growth for Focus Lending in 2017

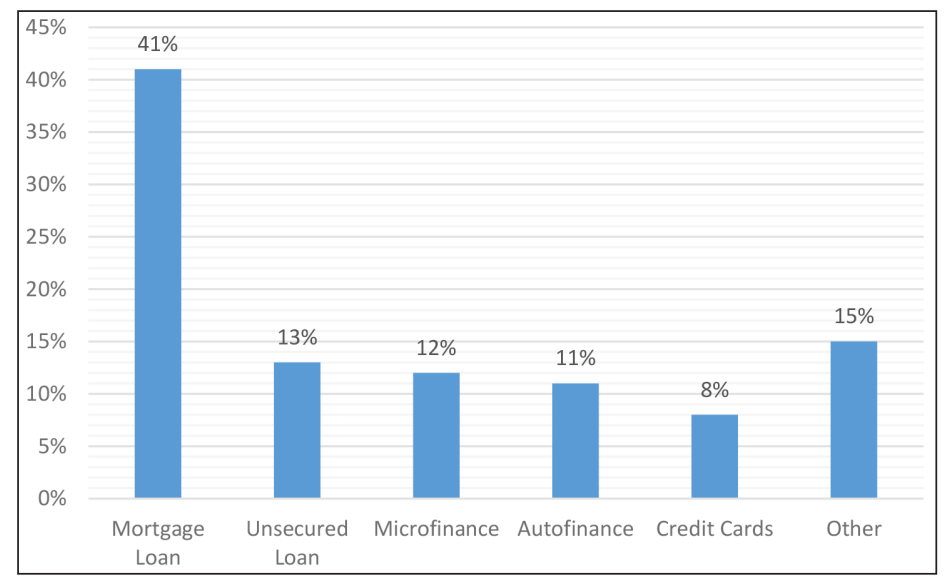

Notes: This figure shows the expected growth in the various lending offer by banks in Indonesia for the year 2017.

The lower growth in microfinancing lending is due to the fact where the credit risk and Non-Performing Loan (NPL) have become one of the big challenges to the growth of lending in 2017. As per the report, majority of banks in Indonesia have viewed that the credit risk and NPL is one of the major obstacles why they cannot give financing to SMEs in Indonesia. Due to higher rate for these two elements, banks have to tighten their credit requirements especially to the mortgage financing and SMEs which usually required higher level of collateral. As reported in Figure 5, the credit risk influences the loan growth by 94 percent followed by margin pressure (75 percent), weak demand (30 percent), liquidity ( 24 percent), regulations (10 percent) and sales (8 percent).

Based on the survey conducted by Ministry of Cooperative and Small Medium Enterprises 2013, only 18 percent of SMEs have access to the financing offered by financial institutions and remaining 82 percent are depending on the internal financing such as their own saving, family members and many others. The banks have make sure the parties requested for funding need to 65 percent of collateral to support the lending and higher lending rates. From the bank perspective, the issue of asymmetric information haunted them since many SMEs are not disclosing accurate information. Thus banks treat the SMEs still under riskiest financing category. Therefore, the bank imposed higher rate and strict rules and regulations. This view is also consistent with the Amianti and Wirayani (2016), they argued that the lack of financing has led to reduction in young entrepreneur to involve in 
business because they find difficulties in start-ups their business. Moreover, given this issue, although there are some entrepreneurs in the line of SMEs, they involve in consumer industry as it required less capital for a start-up the business instead of involving in heavy industry like manufacturing and metal.

Figure 5. Factor influencing the loan growth in 2017 in Indonesia

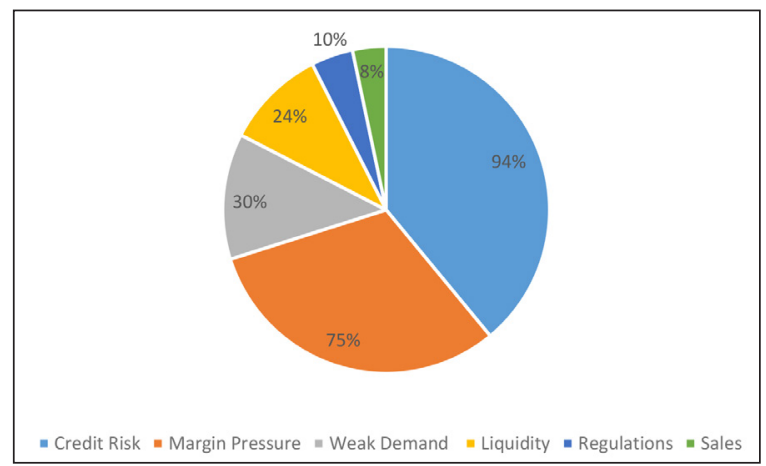

Notes: This figure reveals the information on the challenges facing loan growth in the year 2017 in Indonesia

As per Urata (2000) argument, the problems facing the Indonesian SMEs are consisting of two categories, namely (i) financial problem and (ii) non-financial problem. More emphasis is given to the financial problem as it is the biggest challenges to Indonesian SMEs, whereas the non-financial problems are very common and rarely occurs in SMEs such as organizational management. According to the author, the financial problem is consists of (1) lack of agreement between fund provider and SMEs, and it is not really transparent, (2) there is no efficient way in managing SMEs funding, (iii) involve high transaction costs subsequently caused the use of longer time period in approving funding, (iv) inaccessible to fund as unawareness about the existence of funding, and obviously the high-interest rate which have burdened the poor entrepreneurs as they are in pioneering stage in SMEs business and uncertain about the business success.

On the other hand, Mac Eachern and Suyudi (2014) argued that the problem of financial accessibility by Indonesian SMEs seem to follow the Pecking Order Hypothesis. In other words, the majority of Indonesian SMEs are utilizing and giving priority to the usage of internal funds rather than external funds. This is because, by utilizing the internal, the cost would be lower compared with external funds where need to fulfil many formalities. In addition, the author also 
argued that the terms and conditions, size of the loan, and duration also cause the problem for SMEs' in accessing the financial facility. This issue is very common and used to face by smaller firms, for example, duration factor where the smaller firm expose to higher rejection on financial assistance because unable to fulfil banker requirements in terms of duration of loan. In addition, smaller firms have also needed to pay higher interest rate charges and expose them into the possibility of default risk.

Indeed, the macroeconomic policies implemented by the Indonesian government also have influenced the availability of loanable funds in financial market. Since the government is running with budget deficit, it means that the withdrawal from domestic saving to support the operational costs and investment costs have led the market with limited number of loanable fund which subsequently causes financial institutions to limits their borrowing and lending activities. In 2014, Indonesia attained 2.25 percent budget deficit of gross domestic product (GDP), comparatively higher than the government target of 1.4 percent. This problem will cause a barrier to the SMEs in accessing the financial assistance Shinozaki (2012).

Apart from financial constraints, the Indonesian SMEs is also facing the problem of such: (i) too much of procedures in applying for funding, (ii) high collateral requirement, (iii) lack of information, (iv) not extra business to support, (v) network, (vi) lack of knowledge, (vii) do not fit with business and (viii) others. Although the existing literature has highlighted this issue of financial accessibility, they pay less attention to offer other viable alternative solution in solving the financial accessibility problem rather than just relying on government policies. Hence, with this gap and motivation, the present study has taken a step ahead in exploring the potential of Islamic finance to support the financial accessibility of SMEs in the context of Indonesia.

\section{Islamic banking (IB) and its involvement in SMEs of Indonesia}

The development of Islamic banking (IB) in Indonesia mainly driven society factor or bottom-up in order to meet the needs of society with main priority is focus on the real sector. In contrast compared with Malaysia, the development of IB is more zoom in into financial sector and obtained full support from the government thus, it is called as a government-driven which lead the successful of IB. The number of players involved in Islamic financial industry is also slowly grown since year 2011. Figure 6 below reveals the statistics 
on number of players involved in the Islamic finance industry. It is based on non - bank financial institutions. Basically looking the figures given by Otoritas Jasa Keuangan, OJK (2016), it can noted that the Takaful and Islamic financial industries shows increasing pattern in terms of number of players. The other elements such as Sharia Venture Capital industry, Sharia Specialized industry and Sharia Microfinance (where SMEs involved as well) recorded lower number of players. In Figure 6, the number of players involved in Islamic banking financial institutions are showing increasing pattern, comprises of Islamic commercial banks, Islamic banking unit and Islamic rural banks.

In term total assets, Islamic banking recorded positive CAGR (24.9 percent) from year 2011 until 2016 as compared with conventional banks (14.9 percent). In terms of financing, the growth in Islamic banks is 25.6 percent whereas the conventional banks' percentage is just 17.8 percent (OJK Report, 2016). Based on these two statistics, it can be concluded the acceptance for Islamic banking in Indonesia is slowly in -line with conventional counterparts. Majority of financing in IB, are taking place at commercial businesses instead of SMEs (Huda, 2012).

Figure 6. Islamic Non - Financials Institutions in Indonesia

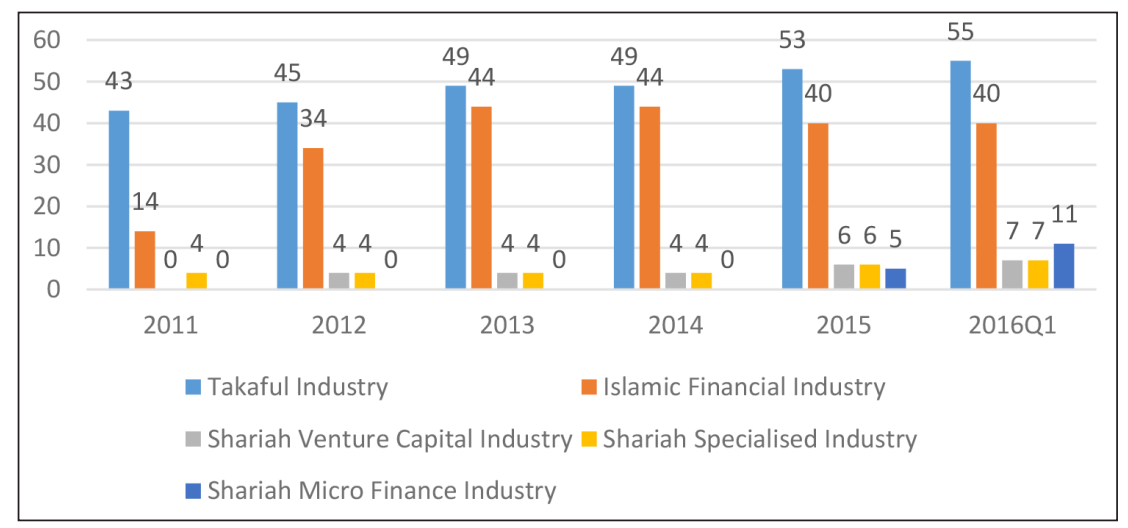

Notes: This figure shows the statistics on the number of the player involved in the Islamic NonFinancial Institutions in Indonesia. The statistics are obtained from the OJK data terminals, and it is from year 2011 till 2016Q1. 
Figure 7. Islamic Banks Financial Institutions

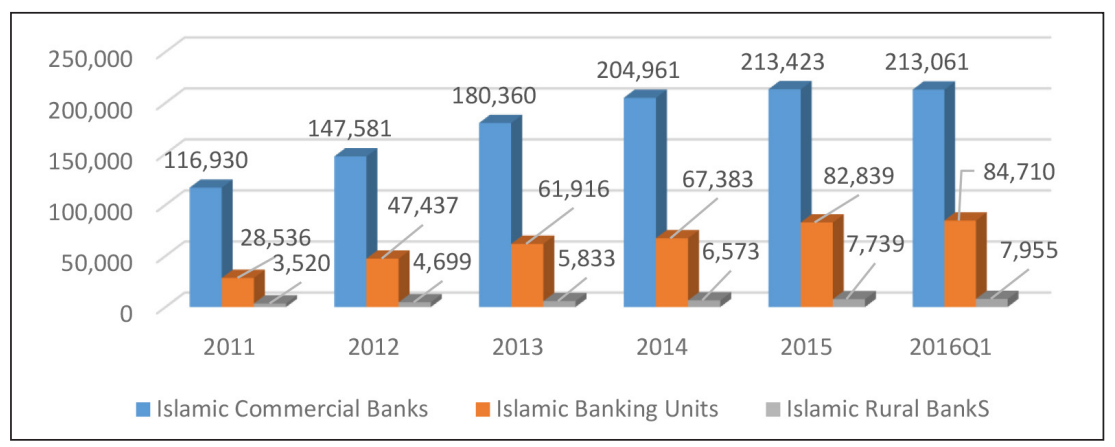

Notes: This figure shows the statistics on the number of players involved in the Islamic Financial Institutions in Indonesia. The statistics are obtained from the OJK data terminals, and it is from year 2011 till 2016Q1.

As evidenced in Figure 6, the microfinancing is not popularly demanded, and the number of players involved is also relatively less in the context of Islamic financial institutions. According to Huda (2012), the less demand for the microfinance and SMEs are due to charges imposed by the IB such as the margin charges and IB focuses to financing working capital for maximum one year only (short term financing). This issues had created big hassle to the development of SMEs in Indonesia as it is not easy not get credit facility form the IB as they tighten the rules and regulations. In addition, the IB in Indonesia provides financing to SMEs mainly in the forms of Murabahah and Musharakah financing. The other financing methods are relatively less in terms of its consumption.

Given this, it has led to difficulties for the young entrepreneur involved in business and subsequently harms the development of SMEs in Indonesian market. The potential of Islamic finance is not fully explored in the context of Indonesian even though there is some Islamic financial product that has been used to support the SMEs. The obstacles such as asymmetric information and moral hazard seem to block the potential of Islamic finance in accelerating social finance via helping the growth of SMEs. Furthermore, those with potential also will be affected due to credit availability. The impact of limited credit and difficulties in accessing to credit facility expected to reduce Indonesian GDP by approximately $\$ 130$ billion which is equal to $14 \%$ of total Indonesian GDP (Bank Indonesia Report, 2015).

Therefore, apart from other issues that haunted the progression of SMEs, it is notable that the issue of financial accessibility is getting critical and need to addressed carefully to maintain the sustainability of SMEs in Indonesia. The 
challenge of financial issue can be overcome by innovative product offerings and policies implementation. In the next section of discussion, the research will share some fruitful lessons or recommendations that the Indonesian can learn from Malaysia who successfully uses and implemented Islamic finance and capital market to support the development of SMEs in general.

\section{What is the recommendation to the Indonesian authority based on Malaysian SMEs successfulness and the potential of Islamic finance?}

Looking at the successfulness of SMEs in Malaysia based on conventional and Islamic financing in terms of financial accessibility. There are some recommendations that can flourish the development and progression of Indonesian SMEs which are having a problem in accessing to get financing. The recommendations are as follows:

i) Diversify the Islamic finance product offerings especially linked to the SMEs financing.

As mentioned in the earlier section, in Malaysia, there are various product offerings in Islamic banking that can help to increase the growth of SMEs. Among the products are Murabahah, Ijarah, Salam, Musharakah, Diminishing Musharakah and Mudharabah. Majority of IBs in Malaysia have already introduced all these instruments to SMEs to support financing accessibility from coverings short-term and long - term requirement of working capital and businesses, which can fit for the SMEs environment. From Indonesian perspectives, the popular Islamic financial instruments that help the SMEs are Murabahah and Musharakah. Other financing tools are limited due to risk-profiles of SMEs and the issues of asymmetric information. Thus, it is recommended to the Indonesia authority, before expanding the Islamic financial tools, the blueprint and strategies need to be developed properly which can allow the introduction of innovative Islamic finance tools. Better monitoring and auditing needed in introducing the tools in the market.

ii) Alternative financing strategies:

\section{Leading Entrepreneur Accelerator Platform (LEAP) Market}

Bursa Malaysia recently has launched a new market specifically for SMEs to raise fund to support its business operation. It is known as the Leading Entrepreneur Accelerator Platform (LEAP). With this new market establishment, the SMEs can raise fund directly from the capital market without going through the financial institutions. The Malaysian SMEs is also facing the issue of financial constraint due to strict rules and regulations from banks side. About 96 percent 
of financing by SMEs are driven by banking sector, and the remaining 4 percent is coming from capital market. Therefore, there is need for innovative financing. Looking at the statistics given by MIDF report (2015), the SME contribution to the business establishment is account for 97 percent and the contribution to the economic development is 37 percent. Thus, with the introduction of LEAP, it will become an alternative financing platform for SMEs. Not only that, with such platform, it would enhance the growth of SMEs in Malaysia. And support broader economic activities.

The trading in LEAP is limited to sophisticated investors (either high-networth individuals whose total assets or annual income exceed RM3 million or RM300,000 respectively or corporates with net assets exceeding RM10 million), (Bursa Malaysia Report, 2017). The listing procedure in LEAP market will be guided by framework issued to Bursa Malaysia and approved by the Securities Commission. Only selected SMEs will participate with assigned approved advisers. SMEs with approved advisers selected: Cloudaron Pte Ltd, Agrofresh International Group Sdn Bhd, Red Ideas Holdings Sdn Bhd, Polymer Link Sdn Bhd, Trustgate Bhd, Accent Wellness Global Sdn Bhd, EastWest One Group Sdn Bhd, Macfeam Sdn Bhd, Upstream Downstream Process $\&$ Services Sdn Bhd, ProEight Sdn Bhd and Safetyware Sdn Bhd. With LEAP, the injection of financing to the SMEs via capital market is expected about 20 percent compared to heavy reliance to of SMEs' financing needs from the present 96 percent by financial institutions. This LEAP applies for both nonSharia and Sharia-compliant SMEs.

\section{Peer to Peer Financing (P2P)}

Another innovative financing that taking place in Malaysia would in the form of Peer to Peer (P2P) financing. This platform specifically for businesses and SMEs for raising capital purpose and it has been recently approved by Securities Commission (SC) of Malaysia to be implemented. By definition, $\mathrm{P} 2 \mathrm{P}$ platform is process of obtaining fund where an individual lends and borrows fund directly from other by using online platform. It means that the role of financial intermediaries is not needed as it is done one to one basis like e-Bay. The P2P financing has successfully implemented in the field of mortgage loan, real estate, education and businesses worldwide. However, in the context of Malaysia, P2P financing is only available for businesses and SMEs. The SC, for the initial stage, had approved six P2P financings in November 2016 and it will fully under operation by the end of December 2017, namely, (i) Funding Societies, (ii) B2B FinPal, (iii) ManagePay, (iv)Fundaztic.com, (v)EthicKapital. 
com, and (vi) FundedByMe Malaysia. With such establishment of innovative financing, Malaysia becomes the first Southeast Asia country the full regulatory control introduced P2P financing. The P2P financing is also applicable for both side Sharia-compliant and Non-Sharia complaint of businesses or SMEs who are looking for financial support (Thaker and Thaker, 2017).

\section{Crowdfunding}

Crowdfunding is a collection of funds (small amount) from many investors or donors through a web-based platform for a specific project, business venture or for the social cause. Crowdfunding can be divided into four categories namely donation crowdfunding, reward crowdfunding, peer-to-peer lending and equity crowdfunding (Thaker and Thaker, 2015). Crowdfunding gained popularity as a creative way to raise fund for various business category namely, philanthropic, social endeavours, entrepreneurial ventures followed by films and performing arts and music and recording arts, and finally energy and environment. The category of crowdfunding that is suitable for SMEs financing would be in the forms of lending, and equity-based crowdfunding as both of these services for raising capital purpose. For example, under equity-based crowdfunding, the fund raised through online by a business, particularly early-stage funding, by offering equity interests in the business to investors. Businesses that are looking to raise capital through this mode typically advertise online through a crowdfunding platform website, which serves as an intermediary between investors and the start-up companies. In Malaysia, the crowdfunding has been successfully implemented in various field, particularly focuses on social-based businesses' such as SMEs. PitchIN is the example of Malaysian crowdfunding platform which based on reward-based has shown rapid progression in South East Asia. PitchIN platform has executed various projects but not limited to Arts \& Design, Photography, Games, Music and businesses. PitchIN also hosts community and social projects, which make up about a third of the projects on site.

In Indonesia, the Crowdfunding is slowly taking its place but with a lot of challenges. One example in Indonesia that successfully used the crowdfunding to raise fund is Kesetkibee program is one of the successful entrepreneurship programs that employing crowdfunding to raise the fund. Kesetkibee is a program that involves only women who are members of the Cooperative Women Unggaran Melati in Central Java. Under this program, the waste material from cloth garment factory is converted into a material with a certain economic value, such as a doormat. Kesetkibee program received funding of Rp 
5.02 million of the total funding needs as much as $\mathrm{Rp} \mathrm{5,000,000.} \mathrm{This} \mathrm{fund}$ was collected from 33 donors who donate through a crowdfunding platform namely patungan.net. Other examples include Craft Programme for Change and GandengTangan which are specifically for small businesses and skills development.

As mentioned earlier, the Crowdfunding platform in Indonesia has potential to utilize properly for SMEs and small businesses, but the challenges such as fraud, failure, anti-money laundering, lack of experiences, regulatory issue and market rejection seem to be continued to harm the progress of Crowdfunding. Again, this platform also can be suited for Sharia and non- Sharia businesses and SMEs.

\section{Investment Account Platform (IAP)}

The IAP is called an online platform that facilitates channeling funds from investors to finance ventures and SMEs and enables them to get access financing effectively and comfortable. Selected Islamic banks in Malaysia such as Affin Islamic Bank, Bank Muamalat Malaysia, Bank Islam Malaysia, Maybank Islamic, Bank Kerjasama Rakyat and Bank Simpanan Nasional have introduced Investment Account Platform (IAP). IAP was launched officially by ex-governor of Malaysian central bank, Dr Zeti Akhtar Aziz on $17^{\text {th }}$ February 2016. The IAP is considered as an online platform that facilitates in channelling funds from investors to finance viable ventures and SMEs. It is a technology-enabled financial marketplace for SMEs to raise funding from a large pool of investors for their businesses via the internet. The IAP is a newly fintech innovative product that offered in Malaysian Islamic banks. In terms of comparison, the IAP, crowdfunding and P2P financings have some similarities, but IAP involved direct financing executed by investors for the project that they like to invest in. With IAP, Islamic banks play a role of intermediation in operationalising the investment account while performs the credit assessments and screening procedure for the projects. However, the IAP requires assistance form rating agencies to rate and screening the ventures and SMEs to make sure it is complying with certain standards. Therefore, the IAP tend to benefits more to the SMEs who needs financial support.

As a concluding remark for alternative financing strategies, the Indonesian authority should consider in implementing the financing strategies applied in Malaysia in boosting up the performance ofSMEsin Indonesia. The improvement needed in making sure the existing financing such as crowdfunding in terms 
of monitoring, improvised the rules and regulations related to crowdfunding, develop better framework in accessing the standard such credit agency to evaluate the project or SMEs before approved the financing. In terms of LEAP and IAP, perhaps the Indonesian government can discuss and collaborate with the Malaysia government and financial authority to implementing the LEAP, P2P and IAP in Indonesian context. There is need for platform for discussion or forum and exchange views or insights on the possibilities to implement these financing strategies in Indonesia with the motive of helping the SMEs. To sum up, the Indonesia authority should realize the potential of FinTechs in lending practices especially in the context of Islamic Banking and finance. The authority is also needed to raise the awareness to the customers and adding value to businesses beyond lending will be vital for long-term growth of banking industry Indonesia.

iii) Information accessibility to enhance the transparency

In Malaysia, the element of asymmetric information is less as there are many sources of information engines where the entrepreneur who looking for financing can gather all the information related to sources of funding. The informations are available in majority of banks website especially the SMEs banks. However, in the context of Indonesia, as per evidence in many literatures, one of main reasons why banks in Indonesia prevent from giving lending SMEs is because of higher asymmetric information. Banks including Islamic banks in Malaysia only give financing to selected ventures by looking at their riskprofiles of the respective ventures. This further adds to the disparity of gaps in terms of financial accessibility of SMEs in Indonesia. As for recommendation, the Indonesian authority should consider providing more data either published or non-published materials on financial assistantship. This will subsequently help to get access to the information easily. If possible, the Indonesian authority should have their own database by working with Islamic financial institutions where the entrepreneur who looks assistance to start-up their business, can easily visit the database to see what are the benefits and assistance available to the entrepreneurs. With this type of arrangement, it is expected to reduce asymmetric information.

iv) Expand the number of "Angel Bank" (AB) for financing alternatives

By definition, $A B$ has known as a process of collects angel investments into a centralized fund, where the bank then vets potential companies and channels the financing to the entrepreneurs and SMEs at lower interest or profit 
charges. Although the $\mathrm{AB}$ is already in the Indonesia market, number of $\mathrm{AB}$ availability is limited. The most of $A B$ in Indonesia is called Angel Investment Network Indonesia. They have successfully provided early-stage capital to entrepreneurs covering various aspects of industries such as technology, consumer, social enterprise and many others. Even in Malaysia, the Angel banks slowly taking its pace of development in helping many young entrepreneurs who are looking for start-up capital for running the businesses. For example, Malaysian Business Angel Network (MBAN), is one of an organization of angel investors and angel clubs in Malaysia which have more than 134 registered angel investors and having net worth of RM123 million in 2016 and supporting various small businesses. When it comes to Islamic finance and $\mathrm{AB}$, the exploration is limited as it involved some profit or interest charges for the service offered. The role of Indonesian authority would be in term of considering the $\mathrm{AB}$ from Islamic finance perspective which means offered the service without the element of riba. This can be done via performing academic research, organizing conference in order to get feedback and reviews from practitioners and academician in introducing $\mathrm{AB}$ which is compliant with Sharia rules. In addition, the Indonesian authority also can consider expanding further the existing $A B$ in all over state while waiting for Islamic finance $A B$ taking place in future.

\section{v) Create more Credit Bureau (CB) for SMEs in Indonesia}

The research workshop that carried out in Hangzhou (2010), APEC workshop, shows a discussion on the Credit Bureau (CB) availability in Indonesia. Under the Indonesian market framework, at the national level, there were two important $\mathrm{CB}$, namely, (i) Askrindo and (ii) Jamkrindo and at regional level there was only one called as Jamkrida Jatim. If compared with Malaysia, there was one agency called Credit Guarantee Corporation of Malaysia in all over states that provide credit information and credit assessments to the financial providers. However, in the context of Indonesia, such a large market for SMEs, the regional credit bureau is only limited to Jamkrida Jatim at Jawa Timur. This itself will become issue in processing the application for funding from other states. In order to smoothen up the processes involved in credit assessments, the Indonesian authority need to develop more credit bureau in all over state, if possible the Indonesian authority consider to provide licensing for Independent Credit Bureau (ICB) where it could be self-funded where it sells the information about customer creditworthiness or their ability to meet debt obligations. This can apply for evaluation for both, Sharia or non-Sharia compliant businesses or SMEs. 


\section{Conclusion}

The role of government and its policies implementation has resulted in a better progression of SMEs in Malaysia. With effective involvement of government in strategized the policies lead the SMEs to records such high achievement and active contribution to the economic growth of Malaysia. As noted, the Malaysia SMEs continued to offer diversified sources of financing to mitigate the need for SMEs in various stages. There is plenty of social financing introduced by conventional and Islamic financing at various stages of SMEs. Moving forward, the SMEs source of financing is slowly become more innovative and take a new turn with innovative platforms such as LEAP, P2P, Crowdfunding and IAP. Together with this, the arrival of FinTech seems to be slowly transforming the financial landscape of Malaysia in Islamic finance and conventional financing. Not only that, apart from FinTech, the product offerings of Islamic banking in Malaysia has resulted SMEs to have more option in selecting the best financing for their ventures. Islamic social financing that offered in Malaysian Islamic banking that widely used by SMEs in Malaysia includes Murabahah, Ijarah, Salam, Musharakah, Diminishing Musharakah and Mudharabah. There are many other as well such as Bay al Dayn, ay al-Innah and Tawarruq.

As far as Indonesian SMEs is a concern, the role of Islamic finance needs to be further enhanced from existing one. The issue of financial accessibility has haunted the progression of SMEs in Indonesia although this industry contributed positively to the growth of Indonesian GDP. There is need for innovative financing strategy to assist the SMEs in accessing the financial assistance. As recommended, the Indonesian government may incorporate some of the ways implemented by Malaysia government in boosting up their SMEs using Islamic finance. Moreover, the findings from this study can be used to develop specific framework in which to increase its capacity in assisting SMEs to access internal and external finances in Indonesia.

\section{References}

Agyei-Mensah, Ben Kwame 2010. "Financial Management Practices of Small Firms in Ghana: An Empirical Study." African Journal of Business Management 5(10): 3781-3793.

Ahmad, Noor Hazlina \& Seet, Pi-Shen. 2009. "Dissecting Behaviours Associated with Business Failure: A Qualitative Study of SME Owners in Malaysia and Australia." Journal of Asian Social Science 5(9): 98-104. 
Aman, Othman \& Md. Nor Hayati Tahir. 2011. "The Success Factors of Food Small and Medium Entrepreneurs Under The One District One Industry Programme: A Case On Food Manufacturing Entrepreneurs In Melaka." Journal of Global Entrepreneurship, 1(1), 44-64.

Amianti, Grace D \& Prima Wirayani. 2016. "Tourism, Digital Economy Help Reduce Joblessness: BPS.” Article published in The Jakarta Post. Retrieved from www.thejakartapost.com.

Bank Indonesia. 2015. Bank Indonesia Report-2015. Retrieved August 31, 2017. from https://www.bi.go.id.

Beh, Behonce. 2013. Why Small Businesses Bite The Dust. Retrieved August 20, 2017. from http://www.focusmalaysia.my/Enterprise/Why-small-businessesbite-the-dust.

Bursa Malaysia Report (2017). Retrieved August 08, 2017. from www.bursamalaysia. com.

Chong, Wu Yi. 2012. "Critical Success Factors for Small and Medium Enterprises: Perceptions of Entrepreneurs in Urban Malaysia." Journal of Business and Policy Research 7(4): 204-215.

Dhumale, Rahul \& Amela Sapcanin. 1999. An Application of Islamic Banking Principles to Microfinance. Technical Note, UNDP.

Economic Report. 2013. Economic Performance and Prospects. Retrieved August 24, 2017. from http://www.treasury.gov.my/pdf/economy/er/1314/chapter3.pdf.

Economic Planning Unit Malaysia. 2017. Socioeconomic Statistic An Overview. Retrieved August 20, 2017. from http://www.epu.gov.my/en/socio-economic/overview.

Economic Planning Unit Malaysia. 2017. Millennium Development Goals Report, 2015. Retrieved August 22, 2017. from http://un.org.my/upload/undp_ mdg_report_2015.pdf.

Economic Planning Unit Malaysia. 2017. New Economic Policy. Retrieved August 24, 2017. from http://www.epu.gov.my/en/development-policies/neweconomic-policy.

Global Business Guide, Indonesia (2016). Indonesia SMEs: Increased Government Support to Overcome Challenges. Retrieved August 25, 2017. From http:// www.gbgindonesia.com/en/main/why_indonesia/2016/indonesia_smes_ increased_government_support_to_overcome_challenges_11603.php.

Hashim, Hafsah. 2015. SME Development Framework: The Malaysian Case. Cairo SME Conference, Eqypt. 
Huda, Aulia Nurul. 2012. "The Development of Islamic Financing Scheme for SMEs in a Developing Country: The Indonesian Case." Procedia Social and Behavioral Sciences, 52: 179-186.

Husin, M.A. \& M D Ibrahim. 2014. "The Role of Accounting Services and Impact on Small Medium Enterprises (SMEs) Performance in Manufacturing Sector from East Coast Region of Malaysia: A Conceptual Paper." Procedia-Social and Behavioural Sciences, 115: 54-67.

Hussein, Norasgikin, Fauziah Noordin \& Hamed Taherdoost. 2015. "The Role of SMEs in Economic Development; Case Study of Malaysia." International Journal of Academic Research in Management (IJARM) 4(3): 77-84.

Kessler, Eric H, Michael A Allocca, \& N Rahman. 2007. "External Knowledge Accession And Innovation Speed In The Small And Medium-Sized Enterprise (SME)." Small Enterprise Research 15(1): 1-21.

Khalique, Muhammad, Abu Hassan Bin Md. Isa, Jamal Nassir Shaari \& A Ageel. 2011. Challenges Faced by The Small and Medium Enterprises (SMEs) In Malaysia: An Intellectual Capital Perspective. International Journal of Current Research 3(6): 398-401.

MacEachern, Elaine \& Aria Suyudi. 2014. "SMEs and Financing in Asia and Financing Vs Other Constraints to SME Development." Presented at the Capacity Building and Training Workshop, Indonesia.

Manan S.K.A., Othman, J., \& Shahadan, A. 2011. Descriptive analysis on the pattern of SME financing in Malaysia, 3rd International Symposium and Exhibition in Sustainable Energy \& Environment, Melaka, Malaysia 1-3 June, 139-147.

Marsh and McLennan Report. 2016. Time for Market Place Lending. Retrieved August 28, 2017.

Mckinsey Survey 2011. Report of SMES Across Selected Economies. Retrieved August 25, 2017. from http://www.mckinsey.com.

Ministry of Cooperatives and SMEs Report. 2012. Retrieved August 25, 2017. from www.mih.gov.kh/.../1_15_2015_7_52_3_01.Panelist(Mr.\%20Meliadi\%20 Sembiring).

Ministry of Cooperatives and SMEs Report. 2012. Retrieved August 27, 2017. from www.mih.gov.kh/.../1_15_2015_7_52_3_01.Panelist(Mr.\%20Meliadi\%20 Sembiring)

Ministry of Finance Malaysia. 2017. 2017 Budget. Retrieved August 25, 2017. from http://www.treasury.gov.my/pdf/budget/speech/touchpoints_budget_2017.pdf 
Ministry of Finance Malaysia. 2017. Economic Report 2013/14. Economic Performance and Prospects. Retrieved August 25, 2017. from http://www.treasury.gov.my/ pdf/economy/er/1314/chapter3.pdf.

NEAC. 2010, New Economic Model for Malaysia, National Economic Advisory Council, Putrajaya, Malaysia.

Nee, E.A. 2016. Budget 2017- Tax Incentives For Businesses Seen as 'limited'. The Sun Daily. 24 October 2016. Retrieved July 16, 2017. from http://www. thesundaily.my/news/2013055.

Nordin, Norization Azim Mohd, Abdul Halim Abdul Hamid \& Chong Chin Woon. 2011. 'Factors Affecting Profitability Of Women Entrepreneur's Business in Malaysia." Annual Summit on Business and Entrepreneurial Studies (ASBES 2011): 972-985.

Nugroho, S.H. 2013. "The Economic Development and The Growth of Small-Medium Enterprises in Indonesia: A Hometown Investment Trust Fund Approach.” Working paper, Graduate School of Public Policy, University of Tokyo, Japan.

OECD. 2016. OECD Economic Surveys Malaysia 2016. Economic Assessment. Available at www.oecd.org/eco/surveys/economic-survey-malaysia.htm. [Accessed on 19 August 2017]

Planning, E. 2015. "Eleventh Malaysia Plan 2016-2020 Anchoring Growth on People." Malaysia: Prime Minister Department.

Otoritas Jasa Keuangan, OJK Report-2016. Retrieved August 27, 2017 from http:// www.ojk.go.id.

Price Water Cooper House Report. 2017. Indonesia Banking Survey, 2017.

Rahman, Yaacob \& Radzi. 2016. "The Challenges Among Malaysian SME: A Theoretical Perspective.” World Journal of Social Sciences 6(3): 124-132.

Saari, M Yusof, Erik Dietzenbacher \& Bart Los. 2015. "Sources of Income Growth and Inequality across Ethnic Groups in Malaysia, 1970 - 2000." World Development, 76: 311-328.

Saleh, Ali Salman \& Nelson Oly Ndubisi. 2006. "SME Development in Malaysia: Domestic and Global Challenges.” Economics Working Paper Series: 1-27.

Shinozaki, S. 2012. A New Regime of SME Finance in Emerging Asia: Empowering Growth-Oriented SMEs to Build Resilient National Economics. ADB Working Paper Series on Regional Economic Integration, ADB.

SME Corp. Malaysia. SMEs Definition. Retrieved from http://www.smecorp.gov. my/index.php/en/policies/2015-12-21-09-09-49/sme-definition). 
SME Annual Report, 2016. Retrieved August 20, 2017 from: http://www.smecorp. gov.my/index.php/en/sme-annual-report-2015-16.

Suzuki, Yasushi \& SM Sohrab Uddin. 2016. "Recent Trends In Islamic Banks' Lending Modes In Bangladesh: An Evaluation." Journal of Islamic Accounting and Business Research, 7(1), 28-41.

Thaker, M.A.M. \& Thaker, H.M.T. 2017. Modelling investors' behavioural intention to invest in Islamic P2P financing in Malaysia. Unpublished manuscript.

Thaker, M.A.M. and Thaker, H.M.T. 2015. "What Is The Solution to Overcome The Financial Challenges Of Smes In Indonesia? Exploiting The Potential Of Crowdfunding In Changing SMES Financial Landscape In Indonesia." Presented at the 9th International Conference, Bulletin of Monetary Economics and Banking, Indonesia. 6th August 2015.

Ting, O. K. 2004. SMEs in Malaysia: Pivotal points for Change. Retrieved August 20, 2017. from http://www.mca.org.my.

Urata, S. 2000. Policy Recommendation for SME Promotion in the Republic of Indonesia.

Wang, S. D. 2003. The Implications of E-Financing: Implications for SMEs, Bulletin on Asia-Pacific Perspective 2003/2004, United Nations, USA.

World Bank-IDB. Annual Report-2015. Retrieved August 27, 2017. from http:// www.isdb.org/irj/portal/anonymous/idb_faq_ar.

World Bank Report. 2014. Retrieved August 16, 2017. from https://www. worldbank.org.

Yoshino, Naoyuki \& Farhad Taghizadeh-Hesary. 2016. "Major Challenges Facing Small and Medium-sized Enterprises in Asia and Solutions for Mitigating Them." ADBI Working Paper, 564: 1-20.

Hoq, Muhammad Ziaul, Nobani Che Ha \& Saad Said Mohd. 2009. "SMEs in the Malaysian Economy.” International Journal of Marketing Studies 1(2): 3-17. 